\title{
THE ROLE OF FINANCIAL PERFORMANCE TO MEDIATE THE EFFECT OF CORPORATE GOVERNANCE ON FIRM VALUE
}

\author{
Niswah Baroroh ${ }^{1 *}$, Linda Agustina ${ }^{2}$ and Trisni Suryarini ${ }^{3}$ \\ ${ }^{1}$ Ms., Universitas Negeri Semarang, INDONESIA,niswahbaroroh@mail.unnes.ac.id \\ ${ }^{2}$ Ms., Universitas Negeri Semarang,INDONESIA, lindaagustina@mail.unnes.ac.id \\ ${ }^{3}$ Ms., Universitas Negeri Semarang, INDONESIA, trisnisuryarini@mail.unnes.ac.id \\ ${ }^{*}$ Corresponding author
}

\begin{abstract}
Corporate Governance is one of the company's assets that is capable of being a characteristic which reflects the values that built the company. The governance that carried out continuously will affect work pattern and company performance. One of the company's performances is financial performance. The aimed of this research are to analyze the effect of financial performance and corporate governance on firm value as individual variable and to analyze the effect of corporate governance to firm value through the financial performance. The population of this research is all Indonesian companies listed in Corporate Governance Performance Index (CGPI) in 2012-2014 as many as 32 companies. The samples used purposive sampling technique and get 22 companies with 66 analysis units. Documentation technique used to collect the data which analyzed by path analysis using Structural Equation Modelling (SEM) by Wrap PLS. The results showed that financial performance could be mediating the effect of corporate governance on firm value; proved by there is a significant effect of corporate governance on financial performance and financial performance on firm value, but there is no significant effect of corporate governance onfirm value.
\end{abstract}

Keywords: corporate governance; financial performance, firm value, price to book value

\section{INTRODUCTION}

Corporate governance is a habit (governance) of a company that becomes characterizes which reflecting the values that built by the company. This on-going habit will affect the work and performance patterns of the company. Corporate governance is a part of intangibles asset of the company that has an important role in shaping firm's value.

Firm's value is a reflection of investors' assessment to the company that is usually used as proxy in Price to Book Value that comparing between market value and book value of the company's shares. Corporate governance informed trough the company's annual report could be a signal for investors to assess the company. Gill (2013) finds a significant positive effect between corporate governance and the value of manufacturing company in America. This is in line with Perdana (2014), which also mentions the significant effect between corporate governance and firm's value.

In accordance with agency theory, which states the difference of the interests between the owner of the company (investor) and the manager of the company (management) causes the need for party who act as a 
mediator of both (investors and managements). Corporate governance is also a control mechanism through the board of commissioners (vice principal) to the management (agent). Good corporate governance will be realized when the interests of the two sides are able to be met well, one of which is embodied in the company's performance.

Nahar (2016) have observed 30 banks in Bangladesh with 7 years of observation, in 2006-2012. He concluded that the characteristics of corporate governance were able to affect banking performance positively significant. In contrast, Bauer (2004) found that corporate governance exactly affected negative to the performance of companies that proxy in Net Profit Margin and Return on Equity. Moreover, Bauer mentioned this negative effect had implications for the unwillingness of companies to estimate corporate profits conservatively.

Financial performance is also quantitative information that can become indicators of investors' assessment to the company. Agustina (2016) mentions that it is evidenced by the significant positive effect between company's performance that proxy in the profitability to the firm's value in the same observation year. Gill (2013) also mentions that the performance of the company proxy in financial leverage and return on assets has positive effect on firm value.

Similar case is stated by Mahendra (2011) and Nahar (2016) who state profitability can influence firm value significantly, because high profitability means there is a guarantee of profit sharing that is also high. However, different case is stated by Tahir (2011), who says that profitability is a ratio that tends to be quiet, only applies at the time, so that its existence has not been able to influence Tobin's $Q$ significantly, further Tahir says continuous ratios felt tend to be able to influence firm value continuously.

In accordance with signaling theory, that all information provided by management to outside parties becomes consideration for decision-making of stakeholders. Corporate governance that is qualitative information and financial performance that is quantitative information become consideration for investors in the selection of their investment decisions. Skerci (2013) states that investors are more fun and easier to compare quantitative information than qualitative information of a company, so this research try to modify some of the previous studies by trying to analyze the roles of the financial performance in the proxy of Debt to equity ratio in mediating the influence between corporate governance mechanisms and firm value armed with a variety of previous studies. This study tries to use variable of corporate governance with index that has been given by the corporate governance performance index (CGPI) as the value of this variable. The hypotheses in this research are below:

$\mathrm{H}_{1}$ : Corporate Governance effect on financial performance

$\mathrm{H}_{2}$ : Financial performance effect on firm value

$\mathrm{H}_{3:}$ Corporate Governance effect on firm value

$\mathrm{H}_{4}$ : Financial performance mediate the effect of corporate governance on firm value

\section{RESEARCH METHOD}

This research was a causality research that measured the relationship between the study variables. This study will prove empirically the existence of causal relationship between Corporate Governance, financial performance and firm value. Hypothesis testing in this study used path analysis with Structural Equation Modelling (SEM) with Wrap PLS.The populations in this study were companies listed in the Corporate Governance Performance Index (CGPI). The selection of sample used purposive sampling technique with three criteria. Sample selection process can be seen in Table 1 below:

Table 1 Sample Selection Prosedure

\begin{tabular}{|l|l|c|c|}
\hline No. & \multicolumn{1}{|c|}{ Criteria } & Excluding Sample & $\begin{array}{c}\text { Total } \\
\text { Sample }\end{array}$ \\
\hline 1 & Companies listed in the CGPI continuously during 2012-2014 & & 32 \\
\hline 2 & Companies whose financial statements are loss & 4 & 28 \\
\hline 3 & Companies that provide required information incompletely & 2 & 26 \\
\hline 4 & Data outliers & 4 & 22 \\
\hline & Total sample & & 22 \\
\hline & The unit of analysis & & 66 \\
\hline
\end{tabular}

Data collection techniques used in this study is documentation techniques. Analysis of the data used descriptive statistical analysis and path analysis by Structural Equation Modeling-Partial Least Square (SEMPLS) with Wrap PLS 


\section{RESULT}

The following table showed the suitability index of cut-off value to be used in examining whether a model was acceptable or fit:

Table 2 Evaluation of Structural Model

\begin{tabular}{|l|l|l|l|}
\hline & \multicolumn{1}{|c|}{ Score } & \multicolumn{1}{c|}{ Guidance } & Information \\
\hline Average path coefficient (APC) & 0,001 & 0,05 & accepted \\
\hline Average block VIF (AVIF) & 1,089 & Ideal $<=3,3$ & accepted \\
\hline Average full collinearity VIF (AFVIF) & 1,223 & Ideal $<=3,3$ & accepted \\
\hline TenenhausGoF (GoF) & 0,33 & Medium $>=0,25$ & medium \\
\hline Sympson's paradox ratio (SPR) & 1 & Ideal $=1$ & accepted \\
\hline $\begin{array}{l}\text { R-squared contribution ratio } \\
\text { (RSCR) }\end{array}$ & 1 & Ideal=1 & accepted \\
\hline Statistical suppression ratio (SSR) & 0,857 & acceptable if $>=0,7$ & accepted \\
\hline $\begin{array}{l}\text { Nonlinear bivariate causality } \\
\text { direction ratio (NLBCDR) }\end{array}$ & 1 & acceptable if $>=0,7$ & accepted \\
\hline
\end{tabular}

Source: secondary data were processed, 2016

Table 2 showed that all of terms of reference have been fulfilled, so that this research model was claimed fit and worthy to be analysed further. As for the output result of hypothesis test can be seen in Table 3 below:

Table 3 Hypothesis Test Results

\begin{tabular}{|c|l|c|c|c|}
\hline No & \multicolumn{1}{|c|}{ Hyphothesis } & P Value & Significant Level & Finding \\
\hline 1 & CG-->DER & 0.006 & $5 \%$ & Accepted \\
\hline 2 & DER-->PBV & 0,006 & $5 \%$ & Accepted \\
\hline 3 & CG-->PBV & 0,296 & $5 \%$ & Rejected \\
\hline 4 & CG-->DER-->PBV & 0,044 & $5 \%$ & Accepted \\
\hline
\end{tabular}

Source: secondary data were processed, 2016

The first hypothesis in this study examined the influence of corporate governance on the debt to equity ratio. The result of statistical analysis showed $\mathrm{P}$ value for the influence of corporate governance on Debt to Equity Ratio (DER) was 0.006 ; far below the number required, that was 0.05 ; so that $\mathrm{H} 1$ was accepted. This was similar to Nahar (2016), which also stated the positive influence between corporate governance and company's performance, but contrary to the research result of Bauer (2003) which found a negative influence between corporate governance and company's performance. The positive influence between the effects of corporate governance to Debt to equity ratio was caused by control and all management of company management mechanisms through existing corporate governance.so as to improve the company's performance in this regard was peroxided through the Debt to Equity Ratio. In accordance with agency theory, it meant the management and board of commissioners have carried out their duties properly, so that good corporate governance was able to form a good company's performance anyway.

The second hypothesis in this study was to examine the effect between company's performance which was proxied by Debt to Equity Ratio (DER) to the firm value that was proxied in Price to Book Value (PBV). The result of statistical analysis presented that DER felt could influence Price to Book Value (PBV) significantly, seen from the $P$ value equal to 0.006 (below 0.05 ) so that $\mathrm{H} 2$ was accepted. This was in line with research from Nahar (2016), which also mentioned the positive influence of company's performance on the firm value. Tanderlilin (2010) stated that companies with high performance means having acquisition guarantee that was better than similar companies with lower performance. According to signaling theory, company's performance became into financial information about the company's condition and effectiveness in the use of existing funds. Of course, this information also became a very important signal for investors to make choices on their investee company.

Debt to Equity Ratio was a ratio that illustrated company's performance by comparing the amount of debt and the company's own capital, which means measuring the ability or the independence of the company to fund its business. It was quite become a signal for investors to determine their investment choices. Companies with DER that was still optimal, allowing investors to invest, related not much interest must be paid as a result of obligations to third parties. 
IJASOS- International E-Journal of Advances in Social Sciences, Vol. III, Issue 9, December 2017

The third hypothesis examined the influence of corporate governance (CG) to the price to book value (PBV). CG was not able to influence directly PBV, evidenced by $\mathrm{P}$ value greater than $\alpha$ that was $5 \%$, so that $\mathrm{H} 3$ was rejected. This was in contrast with the research result of Bauer (2003) who found the negative influence between corporate governance and firm value, slightly different from Nahar (2016) who found that corporate governance had positive effect on firm value. Corporate governance did not effect on firm value directly. Corporate governance was qualitative information that needs to be examined one by one, so it was allowed investors to prefer other factors that could be compared directly one to another in determining investment decisions. It could be concluded that corporate governance information did not affect directly on the firm value with proxy of price to book value.

The next hypothesis in this study was to examine the effect of Corporate Governance to Price to Book Value mediated by Debt to Equity Ratio. Statistical result showed that indirect effect between corporate governance and firm value that was proxied in Price to Book Value (PBV) able to be mediated full by Debt to Equity Ratio (DER), evidenced by $\mathrm{P}$ value equal to 0,044 , less than $5 \%$, so that $\mathrm{H} 4$ was accepted. In contrast to the result of hypothesis 3 testing, that there was no direct effect between corporate governance on firm value, for the information of corporate governance that tend to be qualitative in the company's annual report, and tend to be difficult to be compared to one another, and valued subjective, depending on the view of the reader. The result of this hypothesis test bridged effect between them by adding variable of company's performance with proxy of Debt to Equity Ratio. Debt to equity ratio was a financial ratio that was quantitative, making it easier to be compared one with another. Corporate Governance also affected on the debt to equity ratio. This influence could bridge with variable of price to book value regarding the positive influence between debt to equity ratio on price to book value.

\section{CONCLUSION}

This study proves the roles of Debt to Equity Ratio in mediating influence between corporate governance mechanisms on the price to book value. It is evidenced by the positively significant direct influence between corporate governance mechanisms and debt to equity ratio; and debt to equity with price to book value; but there is no evidence of direct influence between corporate governance mechanisms and price to book value.

\section{REFERENCE LIST}

Agustina, Linda and NiswahBaroroh. (2016). The Relationship between Enterprise Risk Management (ERM) and Firm Value Mediated Through The Financial Performance. Review of Integrative Business \&EconomicsResearch. Vol.5 no.1 pp 128-138.

Bauer, Rob and Roger Otten.(2004). Empirical evidence on corporate governance in Europe.The Effect on Stock Returns, Firm Value and Performance.Journal of Asset Management. August 2004.

Gill,Amirjit and John D Obradovich.(2013). The Impact of Corporate Governance and Financial Leverage on The Value of Amrican Firms. International Research of Finance and Economics, ISSN 1450-2887 Issue 91. (Diaksestanggal 07 Mei 2015).

Mahendra, Alfredo.(2011). Pengaruh Kinerja Keuangan terhadap Nilai Perusahaan (Kebijakan Deviden sebagai Variabel Moderating) pada Perusahaan Manufaktur di Bursa Efek Indonesia.TesisUniversitasUdayana Bali.

Nahar, Shamsun. Christine Jubb and Muhamad I.Azim. (2016). Risk Governance and Performance: a developing country perspective. Managerial Auditing Journal.Vol.31 Iss 31 pp.250-268.

Perdana, Ramadhan Sukma.(2014). AnalisisPengaruh Corporate Governance TerhadapNilai Perusahaan.Diponegoro Journal of Accounting, Volume 3 Nomor 3 Tahun 2014, pp. 1-13.

Sekerci, Naciye.(2013). Does Enterprise Risk Management Create Value for Firms?: Evidence from Nordic Countries. Ph.D thesis, School of Economics and Management, Lund University.

Tahir, IzahMohd and Ahmad Rizal Razali.(2011). The Relationship Between Enterprise Risk Management (ERM) and Firm Value, Evidence From Malaysian Public Listed Companies. International Journal of Economics and Management Science, vol.1 No.2 2011, pp 32-41.

Tanderlilin, (2010).AnalisisInvestasidanTeoriPortofolio.Yogyakarta :Penerbit YKPN 